\title{
POSTMATURITY
}

\author{
By S. G. Clayton, M.D., M.S., F.R.C.S., F.R.C.O.G. \\ Obstetric and Gynaecological Surgeon to King's College Hospital and to Queen Charlotte's and Chelsea Hospitals
}

Although postmaturity is important to both obstetricians and lawyers, there can be tew common conditions in which diagnosis is so uncertain and management so disputed. There is no accepted definition of postmaturity, and if the word were to be applied to all cases in which pregnancy continued beyond the date calculated by Naegele's rule then no less than 40 per cent. of cases would have to be included.

\section{Incidence and Diagnosis}

Although it is often said that patients' menstrual histories are untrustworthy, the frequency of error is exaggerated, and on the whole the menstrual history is the most useful evidence of maturity. The date of ovulation is, of course, unknown, and it is highly improbable that the long physiological process of pregnancy will last exactly the same number of weeks in every case. It, is far more remarkable that 5 per cent. of women are delivered on the calculated date and 65 per cent. within \pm ro days of that date, than that 14 per cent. of women are delivered ro or more days after the expected date (Burger and Korompai, 1939). Another recent study of 14,078 cases (Speitkamp, 1937) shows that the distribution curve of the duration of pregnancy is a smooth curve in which the rise up to the median duration of 282 days from the beginning of the last period closely resembles the fall of the curve after that point, suggesting a chance variation about a mean. From the curve alone there is nothing to suggest that the cases delivered after term are any more ' abnormal' than those delivered shortly before term.

Apart from the menstrual history and the history of cases in which the date of coitus is known, the diagnosis of postmaturity is always uncertain. The size of the foetus can only be estimated roughly, and the natural variation in size of the foetus at term is so great that a reliable assessment of maturity cannot be based on it. For the same reason radiological cephalometry is of little help. Even if the centres of ossification can be seen in a radiograph their time of appearance varies greatly. For example, Adair and Scammon (I92r) found that the centre at the lower femoral epiphysis was present in 5 per cent. of cases before the 32 nd week, in 33 per cent. before the 36 th week, in 86 per cent. before the 40 th week and in 95 per cent. at term. Clinical signs such as 'rigidity' of the foetus, oligohydramnios and changes in the cervix are probably imaginary, being seen just as often before term as after it, and are certainly inconstant.

The incidence of postmaturity may be expressed in various ways. In Table $I$ the percentage of the total number of deliveries taking place in each weekly interval after the 28 oth day is given. Some of the cases were induced or delivered by elective section so that the natural incidence. of postmaturity is a little higher than these figures

Table 1.-Incidence of Postmaturity

Based on all cases delivered in Queen Charlotte's Hospital, 1950-52. Cases of twins, cases of abortion and cases with uncertain dates excluded

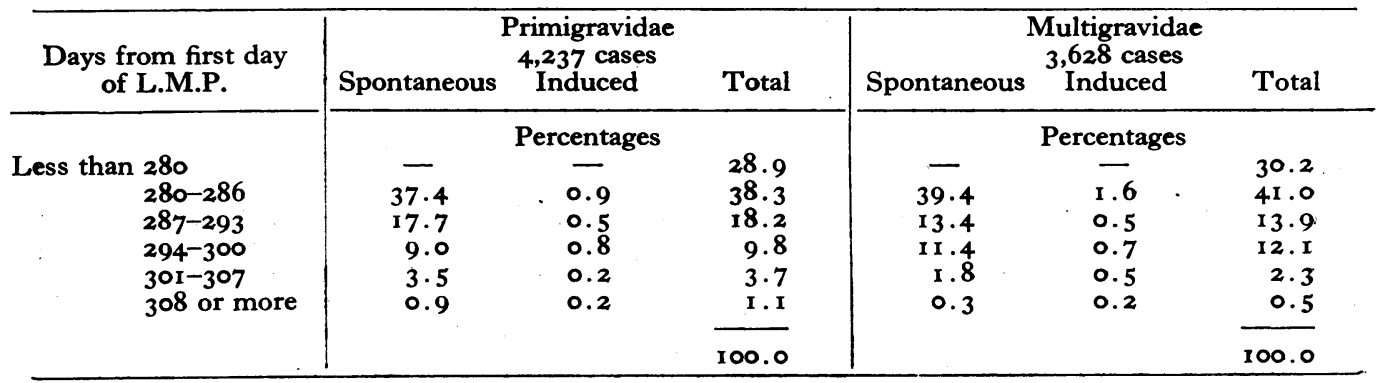


Table 2.-Foetal Mortality

\begin{tabular}{|c|c|c|c|c|c|c|c|c|}
\hline \multirow{2}{*}{\multicolumn{2}{|c|}{ Author }} & \multirow{2}{*}{$\begin{array}{l}\text { Criterion of } \\
\text { post- } \\
\text { maturity }\end{array}$} & \multicolumn{3}{|c|}{ Postmature Cases } & \multicolumn{3}{|c|}{ Mature Gases } \\
\hline & & & Number & Stillborn & Died & Number & Stillborn & Died \\
\hline Clayton (r 94r) & . & $\begin{array}{c}294 \text { days } \\
\text { and over } \\
7 \frac{1}{2} \text { lb. }\end{array}$ & $\begin{array}{c}455 \\
(62 \% \\
\text { primip.) }\end{array}$ & $\begin{array}{l}\text { Per cent. } \\
\quad 6.2\end{array}$ & $\begin{array}{l}\text { Per cent. } \\
0.4\end{array}$ & $\begin{array}{c}8,852 \\
\text { (59\% } \\
\text { primip.) }\end{array}$ & $\begin{array}{c}\text { Per cent. } \\
4.5\end{array}$ & $\begin{array}{l}\text { Per cent } \\
\quad 1.2\end{array}$ \\
\hline Clayton (1953) & . & 294 days & $\begin{array}{c}356 \\
(68 \% \\
\text { primip.) }\end{array}$ & 2.5 & 0.3 & $\begin{array}{c}1,168 * \\
\text { (67\% } \\
\text { primip.) }\end{array}$ & 0.9 & 0.4 \\
\hline McKiddie (I949) & . & $\begin{array}{l}288 \text { days } \\
295 \text { days } \\
\end{array}$ & $\begin{array}{r}1,642 \\
765 \\
\end{array}$ & $\begin{array}{l}2.8 \\
4.3 \\
\end{array}$ & $\begin{array}{l}1.9 \\
2.0 \\
\end{array}$ & 3,366 & $1 \cdot 3$ & I. 4 \\
\hline Racker, Burgess a & nd Manly (1953) & $\begin{array}{l}287 \text { days } \\
294 \text { days }\end{array}$ & $\begin{array}{r}410 \\
\times 49 \\
\end{array}$ & $\begin{array}{l}4.6 \\
8.7 \\
\end{array}$ & 二 & \} 1,229 & $\mathrm{I} \cdot \mathbf{5}$ & - \\
\hline
\end{tabular}

*Cases taken at random from the same year and delivered in the 4 oth week.

indicate. These figures agree with those of Speitkamp (1937) who found that 4.4 per cent. of women were delivered after the 299th day. McKiddie (1949) studied 6,803 cases and found that 13 per cent. of women were delivered when 8 to 14 days past term, 6.2 per cent. when $I_{5}$ to 2 I days past term and 1.9 per cent. when 29 or more days past term. The number of cases induced is not stated. Racker, Burgess and Manly (1953) found that 25 per cent. of women were delivered after the 287 th day and 9 per cent. after the 294th day. These figures are of more than academic interest, for they indicate the number of cases that will be induced at a particular date by an obstètrician who believes in this treatment.

\section{Foetal Mortality}

The most important point in this discussion is the foetal risk of postmaturity. If the foetal risk is increased what is the reason? It may seem superfluous to remark that observations on " postmature' cases are useless unless the records are conscientiously scrutinized. This is a tedious task if large numbers are included, but anyone who undertakes it will be astonished at the inaccuracy with which the duration of pregnancy is entered in ordinary hospital notes. In comparisons between mature and postmature cases (however defined) the proportions of primigravidae and multigravidae must also be considered, as the groups are otherwise hardly comparable, a point that most recent authors have ignored.

Several recent studies of the foetal mortality in postmature cases have been made, and Table 2 shows some of the results.

If it is agreed, on the evidence of these figures, that the foetal mortality is higher in cases delivered after term than in ordinary mature cases, then we must seek the reason for this. Is it due to inadequate placental function or is it due to difficulto labour? It is surprisingly difficult to give a con $\vec{t}$ fident answer to this question. Errors due to theo uncertainty of diagnosis of postmaturity are largely_ overcome if big groups of cases are considered, but we still have to assess the difficulty of delivery ' which is affected by so many factors, including parity and the weight of the foetus.

Few studies of the stillbirths and neonatal deat in postmature cases have been made. This attempted in my own series (1941, 1953) and the results are summarized in Tables 3 and 4 .

There was no instance of intrauterine deatho before the onset of labour. It is not affirmed that such deaths never occur in postmature cases $\overrightarrow{\overrightarrow{0}}$ but it is maintained that such cases are uncommon 3 Unexplained intrauterine death is as common be? fore term as after it. Latto (I95I), for example? studied ${ }_{54}$ stillbirths and found that 21 foetuseso died in utero without obvious cause, but that only? two of these were postmature. If an unexplainedo foetal death occurs before term the obstetrician has little sense of failure as the accident coulde neither be foreseen nor prevented, but if death occurs after full term he often attributes it to post- -5 maturity and feels responsible for the disaster.

Reference to the tables will show how many of the cases of foetal death after term had other gross obstetric complications. (The improvement in obstetric practice between $194 \mathrm{r}$ and 1953 is alsoo evident in the tables.) It is always difficult tow determine the exact cause of a stillbirth, and it is, of course, possible that placental inadequacy waso present and partly accounted for some of thesed stillbirths. In at least seven cases there was no? serious obstetric difficulty, and these deaths might be attributed to postmaturity, but it must not be forgotten that these were the only such cases found? among a total of more than 15,000 deliveries. 
Table 3.-Causes of Foetal Death Among 455 Postmature Cases (Clayton, i 94I)

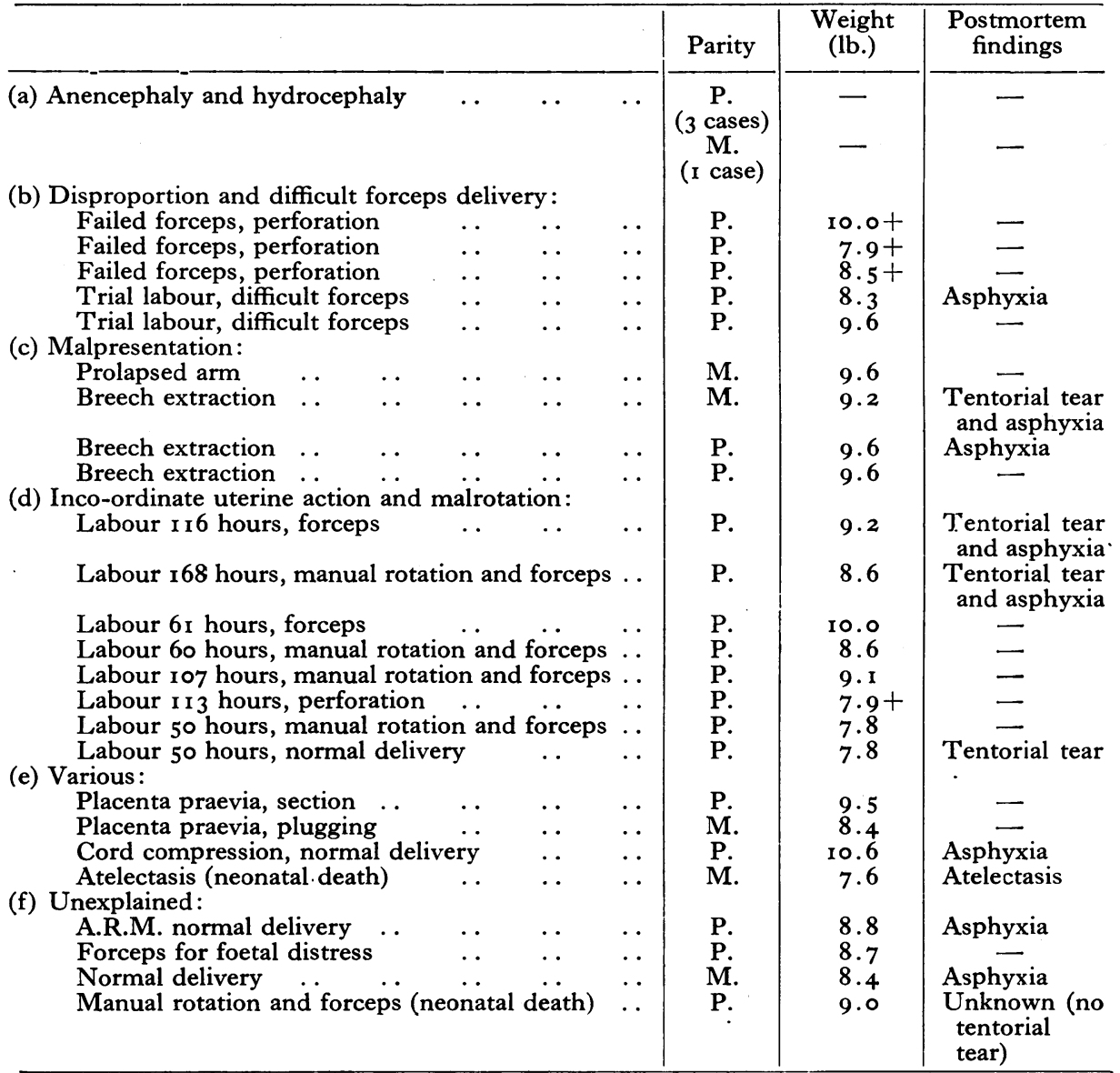

Table 4.-Causes of Foetal Death Among 356 Postmature Cases (Clayton, i 953)

\begin{tabular}{|c|c|c|c|c|c|c|}
\hline & & & & Parity & $\begin{array}{l}\text { Weight } \\
\text { (lb.) }\end{array}$ & $\begin{array}{l}\text { Postmortem } \\
\text { findings }\end{array}$ \\
\hline $\begin{array}{l}\text { (a) Anencephaly .. } \\
\text { (b) Difficult forceps } \\
\text { (c) Inco-ordinate uterine action: } \\
\text { Manual rotation and forceps } \\
\text { (d) Various: } \\
\text { Pre-eclampsia, A.R.M. } \\
\text { Cord four times round neck } \\
\text { Prolapsed cord . } \\
\text { Concealed accidental A.P.H. } \\
\text { Atelectasis (neonatal death) } \\
\text { (e) Unexplained: } \\
\text { Low forceps for delay } \\
\text { Labour 5I hours, normal delivery } \\
\text { Normal labour, 4r hours ... }\end{array}$ & $\begin{array}{l}0 \\
0 \\
0 \\
.\end{array}$ & $\begin{array}{l}\cdots \\
\cdots \\
\cdots \\
\cdots\end{array}$ & $\begin{array}{l}\cdots \\
\cdots \\
\cdots \\
\cdots \\
\cdots \\
\cdots \\
\cdots \\
\cdots \\
\cdots \\
\cdots\end{array}$ & $\begin{array}{l}\text { M. } \\
\text { P. } \\
\text { P. } \\
\text { P. } \\
\text { P. } \\
\text { M. } \\
\text { M. } \\
\text { M. } \\
\text { P. } \\
\text { P. }\end{array}$ & $\begin{array}{l}7 . \\
8.4 \\
7.9 \\
\\
5.9 \\
7.0 \\
7.7 \\
6.9 \\
8.9 \\
6.4 \\
7.9 \\
7.4\end{array}$ & $\begin{array}{l}\text { Tentorial tear } \\
\text { Asphyxia } \\
\text { Tentorial tear } \\
\text { Atelectasis } \\
\text { Asphyxia }\end{array}$ \\
\hline
\end{tabular}


Table 5.-Incidence of Prolonged Labour (Clayton, 1953)

\begin{tabular}{|c|c|c|c|c|c|}
\hline Maturity & & $\begin{array}{c}\text { Average } \\
\text { duration } \\
\text { of } \\
\text { labour }\end{array}$ & $\begin{array}{c}\text { Labour } \\
\text { more } \\
\text { than } \\
24 \\
\text { hours }\end{array}$ & $\begin{array}{c}\text { Labour } \\
\text { more } \\
\text { than } \\
48 \\
\text { hours }\end{array}$ & $\begin{array}{l}\text { Forceps delivery } \\
\text { or Caesarean } \\
\text { section for } \\
\text { delay or } \\
\text { mechanical } \\
\text { difficulty }\end{array}$ \\
\hline Primigravidae: & & Hours & $\%$ & $\%$ & $\%$ \\
\hline 40 weeks $(737$ & . & 19.8 & 21 & 4.2 & $15 \cdot 7$ \\
\hline $\begin{array}{l}42 \text { or more weeks ( } 239 \text { cases) } \\
\text { Multigravidae: }\end{array}$ & & 24.2 & 37 & 12.1 & 27.6 \\
\hline $\begin{array}{l}40 \text { weeks }(385 \text { cases) } \\
42 \text { or more weeks (II } 3 \text { cases) } \ldots\end{array}$ & . & $\begin{array}{r}9.8 \\
12.9\end{array}$ & $\begin{array}{l}6.5 \\
8.1\end{array}$ & $\begin{array}{l}0.8 \\
1.8\end{array}$ & $\begin{array}{r}5.2 \\
13.3\end{array}$ \\
\hline
\end{tabular}

Table 6.-Incidence of Foetal Distress and Stillbirth (from McKiddie, 1947)

\begin{tabular}{|c|c|c|c|c|}
\hline \multirow{2}{*}{ Weeks } & \multirow{2}{*}{$\begin{array}{l}\text { Incidence of } \\
\text { foetal distress } \\
\text { in utero }\end{array}$} & \multirow{2}{*}{$\begin{array}{l}\text { Incidence of } \\
\text { foetal distress } \\
\text { at birth }\end{array}$} & \multicolumn{2}{|c|}{ Stillbirth rate } \\
\hline & & & Total & Unexplained \\
\hline $\begin{array}{c}40 \\
41 \\
42 \\
43 \\
14 \text { or more }\end{array}$ & $\begin{array}{l}\text { Per cent. } \\
\left.\begin{array}{r}5.7 \\
9.9 \\
9.7 \\
x 0.2\end{array}\right\} 7.6\end{array}$ & $\begin{array}{l}\text { Per cent. } \\
\left.\begin{array}{l}7.4 \\
7.6 \\
5.6 \\
3.9\end{array}\right\} 6.9\end{array}$ & $\begin{array}{c}\text { Per cent. } \\
\text { I.3 } \\
2.8\end{array}$ & $\begin{array}{c}\text { Per cent. } \\
0.3 \\
\}_{1.1}\end{array}$ \\
\hline
\end{tabular}

Table 7.-Incidence of Foetal Distress, and Unexplained Stillbirth (Clayton, 1953)

\begin{tabular}{|c|c|c|c|c|c|c|}
\hline \multirow[b]{2}{*}{ Weeks } & \multicolumn{2}{|c|}{ Primigravidae } & \multicolumn{2}{|c|}{ Multigravidae } & \multicolumn{2}{|c|}{ All cases } \\
\hline & $\begin{array}{l}\text { No. of } \\
\text { cases }\end{array}$ & $\begin{array}{c}\text { Foetal } \\
\text { distress or } \\
\text { unex- } \\
\text { plained } \\
\text { stillbirth }\end{array}$ & $\begin{array}{l}\text { No. of } \\
\text { cases }\end{array}$ & $\begin{array}{l}\text { Foetal } \\
\text { distress or } \\
\text { unex- } \\
\text { plained } \\
\text { stillbirth }\end{array}$ & $\begin{array}{l}\text { No. of } \\
\text { cases }\end{array}$ & $\begin{array}{l}\text { Foetal } \\
\text { distress or } \\
\text { unex- } \\
\text { plained } \\
\text { stillbirth }\end{array}$ \\
\hline $\begin{array}{c}40 \\
42 \\
43 \\
44 \text { or more } \\
\end{array}$ & $\begin{array}{r}783 \\
138 \\
81 \\
24 \\
\end{array}$ & $\left.\begin{array}{l}\text { Per cent. } \\
5.6 \\
\text { I3 } 3 \\
\text { 1 } 1 \\
8\end{array}\right\} 12$ & $\begin{array}{r}385 \\
60 \\
38 \\
15\end{array}$ & $\begin{array}{l}\text { Per cent. } \\
\begin{array}{l}\mathbf{5} \cdot 3 \\
-\}^{1}\end{array} 2.7\end{array}$ & $\begin{array}{rl}1 & 168 \\
198 \\
119 \\
39\end{array}$ & $\left.\begin{array}{l}\text { Per cent. } \\
4.9 \\
10.6 \\
7.6 \\
5.1\end{array}\right\} 9.0$ \\
\hline
\end{tabular}

The high incidence of prolonged labour and of instrumental delivery for mechanical difficulty is striking among the postmature cases (Table 5).

The foetal head continues to grow after full term, the biparietal diameter increasing by about I $\mathrm{mm}$. per week (Crichton, 1952). In a case of borderline disproportion this will increase the difficulty, but if the cases are subdivided into groups with comparable foetal weights the incidence of prolonged labour is still found to be higher in the postmature cases in each group, and this suggests that the delay is partly due to abnormal uterine action (Clayton, I94I, 1953). This point may influence the obstetrician's attitude towards the induction of labour.

Although the factor of difficult labour has been emphasized here, several recent investigations have furnished evidence of inadequate placental function in postmaturity. There is no evident anatomical change in the placenta. Histological section, studies of calcium deposits and perfusion of the foetal blood vessels have failed to show any 의 abnormality (Masters and Clayton, 1940). The $D$ scanty evidence suggests that the permeability of the placenta increases progressively up to full $N_{0}$ term, and there is nothing to suggest any subsequent retrogression.

In a valuable paper published in 1949 McKiddie $N$ drew attention to the increased incidence of foetal $O$ distress in postmature cases and also of un- 0 explained stillbirths (Table 6). My own observations confirm this but also show a great difference $\stackrel{\mathscr{\rho}}{?}$ between the risk in primigravidae and multi- $T$ gravidae (T'Table 7).

McKiddie attributed the foetal distress to $\stackrel{\mathbb{O}}{\mathscr{Q}}$ failure of oxygenation because of changes in the $\stackrel{\odot}{\perp}$ 
maternal blood flow through the placenta. In many mammals the blood flow through the uterus, and presumably through the placenta, diminishes in late pregnancy. At the same time the cardiac output falls, probably because of closure of the 'uterine 'shunt.' Although there is no direct proof of diminished maternal blood flow through the human placenta the cardiac output falls in late pregnancy, just as it does in other species (Palmer and Walker, I949; Hamilton, I949). Yet the difference in the incidence of foetal distress in primigravidae and multigravidae (Table 7 ) requires explanation. Is it only due to the ease of labour in multigravidae or is there some difference in the maternal blood flow? Reynolds (1939) suggested that the placental blood volume is reduced at term because of pressure from the growing foetus, and presumably this effect would be greater in the tense primigravid uterus.

During investigations on foetal haemoglobin levels Walker and Turnbull (1953) approached the problem differently but concluded that 'there is usually a gradual fall in the oxygen content and oxygen saturation' of the cord blood ' as term approaches, and in association with this there is a rise in the haemoglobin and red cell levels. The rise in production of haemoglobin is proportional to the fall in oxygen supply. If the duration of pregnancy exceeds $4 \mathrm{I}$ weeks the fall in oxygen content and the rise in haemoglobin and red cell levels are substantial.'

In some animals labour can be postponed by injections of progesterone, and the large foetuses die in utero (Snyder, 1934). Such experiments have little significance for the obstetrician, as the degree of overgrowth is extreme and has no parallel in human postmaturity. The ratio of the weight of the uterine contents to the weight of the mother is much greater, and the normal duration of pregnancy less, than in human pregnancy. Indeed several writers (e.g. McKiddie, 1949) have suggested that the postmature human foetus may lose weight in utero. There is little evidence to support this except the observation that in some series the mean weight of children born at each weekly interval increases up to the 43 rd week but not afterwards. This finding is just as likely to be due to the erroneous inclusion of women who are a month out in their dates, and these cases obscure and 'dilute' the few cases that are genuinely a month overdue. Even if placental function is failing such a loss of weight is improbable; there is no analogy with the rapid loss of weight that occurs with underfeeding in extra-uterine life. In the uterus the foetus has little heat loss and no loss of fluid by respiration.

This review may have shown the difficulty of investigating this subject. Only tentative con- clusions, hardly more than expressions of opinion, can be offered. The diagnosis of postmaturity is impossible without a clear menstrual history and is even then uncertain. The risk of intrauterine death before the onset of labour is small, of the order of $I$ in 2,000. There is considerable risk of toetal distress during labour, probably due to placental inadequacy, but also in part due to difficult labour and especially to inco-ordinate uterine action. The stillbirth rate is increased but there is little if any increase in the neonatal death rate.

\section{Management}

With these conclusions in mind we may now ask whether labour should be induced for postmaturity. The uncertainty of diagnosis means that any wholesale method of treatment will lead to much unnecessary induction. From the figures above it will be seen that roughly 25 per cent. of cases will be undelivered when a week overdue, Io per cent. when two weeks overdue and 4 per cent. when three weeks overdue. If we recommend induction when are we to interfere? It has not been shown that there is an abrupt increase in risk at any particular stage of postmaturity.

It is often said that a medical induction may be safely used as a test for maturity, but even a medical induction is not entirely without risk if pitocin is used, and it is an unconvincing test. For example, in 50 consecutive inductions (consisting of an enema and pitocin injections) given after the 42nd week no less than $3^{I}$ failed. This treatment is likely to increase the patient's impatience rather than to help her.

Racker, Burgess and Manly (1953) have advocated rupture of the membranes as a routine on the expected date of delivery. Their paper is most interesting and they claim that their results are improved by induction, but the figures do not show the proportions of primiparae and of abnormal cases in the treated and control groups, nor the neonatal death rate, nor the causes of the foetal deaths. Many figures have been published to show the foetal risk of induction but these are not of much use in our discussion as so many of the cases were premature. What we have to discover is the risk of surgical induction at or after full term. Table 8 will show that the procedure is not without risk. Although the total foetal mortality was 6.5 per cent. five deaths were obviously unconnected with the induction. But in 16 per cent. of the cases there was an induction-delivery interval of over three days and eight ( 3.2 per cent.) foetal deaths were due to asphyxia, mostly in these cases of delay. This risk was the same in the "postmature' cases. In the series of Racker, Burgess and Manly, consisting of 162 cases, the induction- 
Table 8-Results of Sugical Induction

All cases induced by rupture of the membranes at or after full term in Queen Charlotte's Hospital, 1948-1951. Nearly all the cases of pre-eclampsia were slight cases.

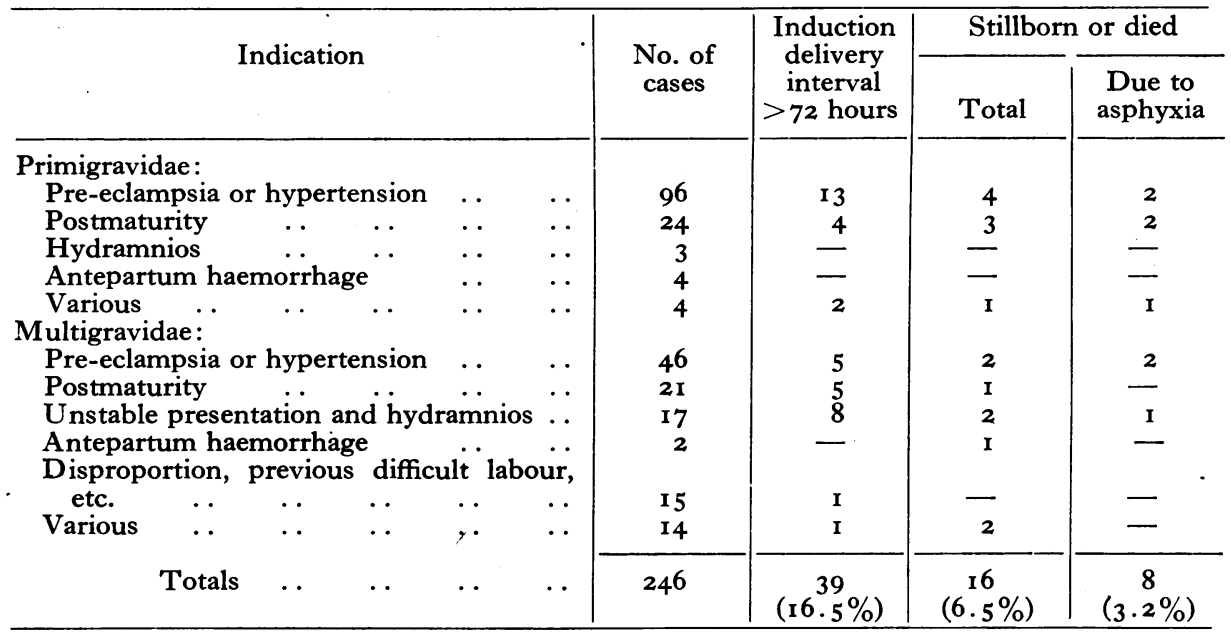

delivery interval was more than 48 hours in $3 \mathrm{I}$ cases and several very long intervals were mentioned, with at least one foetal death due to the delay. Are we really reducing the risk of foetal asphyxia and infection by such treatment, which will have to be applied to about 30 per cent. of the cases? In my opinion more harm than good will result, but it will be interesting to see the experiment repeated by others who share the views of Racker and his colleagues.

Since the risk of intrauterine death before the onset of labour seems to be small, and since the diagnosis of postmaturity is so uncertain, I feel that surgical induction is seldom justifiable. The risk of inco-ordinate uterine action and of foetal distress in labour may be increased rather than diminished, but I can offer no statistical proof of this. There can, however, be general agreement on the risk of foetal distress during labour and in every postmature case a particular watch should be kept. Any suspicion of foetal distress would $\stackrel{\circ}{\triangle}$ justify immediate delivery by section if the cervix is not fully dilated. Mechanical difficulties and inco-ordinate uterine action are common complica- $\vec{\theta}$ tions in postmature cases and add to the risk.

\section{BIBLIOGRAPHY}

ADAIR, F. L., and SCAMMOM, R. E. (1921), Amer. F. Ob Gyn., 2, 35 .

BURGER, K., and KOROMPAI, I. (1939), Zentralb. f. Gynak. 63, 1290.

CLAYTON, S. G. (1941), F. Obst. Gyn. Brit. Emp., 48, 460.

CLAYTON, S. G. (1953), Proc. Roy. Soc. Med., 46, 91 .

CRICHTON, D. (1952), Ibid., 45, 535.

HAMILTON, H. F. H. (1949), Ұ. Obst. Gyn. Brit. Emp., 56, 548. LATTO, D. (195I), Brit. med. F., i, 1346.

MCKIDDIE, J. M. (1949), f. Obst. Gyn. Brit. Emp., 56, 386.

MASTERS, M., and CLAYTON, S. G. (1940), Ibid., 47, 437.

PALMER, A. J., and WALKER, A. H. C. (1949), Ibid., 56, 537. RACKER, D., BURGESS, G. H., and MANLY, G. (1953), Lancet, ii, 953 .

REYNOLDS, S. R. M. (1939), ' Physiology of the Uterus,' Hoeber, New York.

SNYDER, F. F. (1934), Bull. Fohns Hopk. Hosp., 54, I.

SPEITKAMP, L. (1937), Ztschr. f. Geburtsh. u. Gynak., 116, 10.

WALKER, J., and TURNBULL, E. P. N. (1953), Lancet, ii, 312

\section{$\mathrm{HOW}$

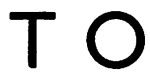 \\ G E T \\ THER E}

An Address Book for the Medical profession, showing how to reach the various Colleges, Societies, Institutes and Hospitals in and near London. Third Edition: 1950

Published by the

FELLOWSHIP OF POSTGRADUATE MEDICINE 60 Portland Place, London, W.I 